S A Journal of Industrial Engineering, vol 8, No 1, June 1994, pp38-52

\title{
THE MALCOLM BALDRIDGE NATIONAL QUALITY AWARDS
}

\author{
Schalk J Claasen \\ Pr Eng
}

\section{Department of Industrial and Systems Engineering \\ University of Pretoria}

\begin{abstract}
The Malcolm Baldridge National Quality Awards are similar in nature to the National Productivity Awards, which are annually presented by the NPI, in recognition of outstanding achievements in productivity improvement. These awards are managed by the National Institute of Standards and Technology (NIST) of the USA and are presented to American Companies in recognition of outstanding quality achievements. In this paper the core values and examination criteria of the Malcolm Baldridge National Quality Awards will be discussed.
\end{abstract}

\section{OPSOMMING}

Die Malcolm Baldridge Nasionale Kwaliteitstoekennings is vergelykbaar met die Nasionale Produktiwiteitstoekennings, wat jaarliks deur die NPI gemaak word, om uitstaande prestasie op die gebiede van produktiwiteitsverbetering te erken. Hierdie pryse word deur die Nasionale Instituut van Standaarde en Tegnologie (NIST) van die VSA administreer en word aan Amerikaanse firmas toegeken as erkenning vir uitstaande kwaliteitsprestasies. In hierdie referaat sal die kernwaardes en beoordelingskriteria van die Malcolm Baldridge Nasionale Kwaliteitstoekennings bespreek word. 


\section{INTRODUCTION}

The Malcolm Baldrige National Quality Improvement Act of 1987, signed by President Reagan on August 20, 1987, established an annual U.S. National Quality Award. The purposes of the Award are to promote awareness of quality excellence, to recognize quality achievements of U.S. companies, and to publicize successful quality strategies. The Secretary of Commerce and the National Institute of Standards and Technology (NIST, formerly the National Bureau of Standards) have responsibility to develop and administer the Award with cooperation and financial support from the private sector.

The award is named for Malcolm Baldridge, who served as Secretary of Commerce from 1981 until his death in a rodeo accident in 1987. His managerial excellence contributed to long-term improvement in the efficiency and effectiveness of government.

Up to two Awards may be given each year in each of three categories namely:

- manufacturing companies or subsidiaries,

- $\quad$ service companies or subsidiaries and

small businesses.

\section{CORE VALUES AND CONCEPTS}

The Baldridge Award criteria are built on ten core values and concepts. These core values and concepts are:

\section{Customer-Driven Quality}

Quality is judged by the customer. All product and service attributes that contribute value to the customer and lead to customer satisfaction and preference must be the foundation for a company's quality system. Value, satisfaction, and preference may be influenced by many factors throughout the customer's overall purchase, ownership, and service experiences. These factors include the company's relationship with customers that helps build trust, confidence, and loyalty. This concept of quality includes not only the product and service attributes that meet basic customer requirements, but it also includes those that enhance them and differentiate them from competing offerings.

Customer-driven quality is thus a strategic concept. It is directed toward customer retention and market share gain. It demands constant sensitivity to emerging customer and market requirements, and measurement of the factors that drive customer satisfaction and retention. It also demands awareness of developments in technology, and rapid and flexible response to customer and market requirements. 
Such requirements extend well beyond defect and error reduction, merely meeting specifications, and reducing complaints. Nevertheless, defect and error reduction and elimination of causes of dissatisfaction contribute significantly to the customers' view of quality and are thus also important parts of customer-driven quality. The company's success in recovering from defects and errors ("making things right for the customer") is crucial to building customer relationships and to customer retention.

\section{Leadership}

A company's senior leaders must create a customer orientation, clear and visible quality values, and high expectations. Reinforcement of the values and expectations requires substantial personal commitment and involvement. The leaders must take part in the creation of strategies, systems, and methods for achieving excellence. The systems and methods need to guide all activities and decisions of the company. The senior leaders must commit to the growth and development of the entire work force and should encourage participation and creativity by all employees. Through their regular personal involvement in visible activities, such as planning, communications, review of company quality performance, and recognizing employees for quality achivement, the senior leaders serve as role models reinforcing the values and encouraging leadership in all levels of management.

\section{Continuous Improvement}

Achieving the highest levels of quality and competitiveness requires a well-defined and well-executed approach to continuous improvement. The term "continuous improvement" refers to both incremental and "breakthrough" improvement. A focus on improvement needs to be part of all operations and of all work unit activities of a company.

\section{Employee Participation and Development}

A company's success in meeting its quality and performance objectives depends increasingly on work force quality and involvement. The close link between employee satisfaction and customer satisfaction creates a "shared fate" relationship between companies and employees. For this reason, employee satisfaction measurement provides an important indicator of the company's efforts to improve customer satisfaction and operating performance. Improving company performance requires improvements at all levels within a company. This, in turn, depends upon the skills and dedication of the entire work force. Companies need to invest in the development of the work force and to seek new avenues to involve employees in problem solving and decision making. Factors that bear upon the safety, health, wellbeing, and morale of employees need to be part of the company's continuous improvement objectives. Increasingly, training and participation need to be tailored to a more diverse work force, and to more flexible work organizations. 


\section{Fast Response}

Success in competitive markets increasingly demands ever-shorter cycles for new or improved product and service introduction. Also, faster and more flexible response to customers is now a more critical requirement of business management. Major improvements in response time often require work organizations, work processes and work paths to be simplified and shortened. To accomplish such improvement more attention should be given to measuring response time performance. This can be done by making response time' a key indicator for work unit improvement processes. There are other important benefits derived from this focus: response time improvements often drive simultaneous improvements in organization, quality, and productivity. Hence it is beneficial to consider response time, quality and productivity objectives together.

\section{Design Quality and Prevention}

Quality systems should place strong emphasis on design quality - that is problem and waste prevention achieved through building quality into products and services and into the processes through which they are produced. In general, costs of preventing problems at the design stage are much lower than costs of correcting problems which occur "downstream". Design quality includes the creation of fault-tolerant (robust) processes and products.

A major issue in the competitive environment is the design-to-introduction ("product generation") cycle time. Meeting the demands of ever-more rapidly changing markets requires that companies carry out stage-to-stage coordination of functions and activities from basic research to commercialization.

\section{Long-Range Outlook}

Achieving quality and market leadership requires a company to have a strong future orientation and a willingness to make long-term commitments to customers, employees, suppliers, stockholders, and the community. Planning needs to determine or anticipate many types of changes including those that may affect customers' expectations of products and services, technological developments, evolving regulatory requirements and community/societal expectations. Plans, strategies, and resource allocations need to reflect these commitments and changes. A major part of the long-term commitment relates to the development of employees and suppliers, and to fulfilling public responsibilities and serving as a corporate citizenship role model.

\section{Management by Fact}

Pursuit of quality and operational performance goals of the company requires that 
process management be based upon reliable information, data, and analysis. Facts and data needed for quality improvement and quality assessment are of many types, including: customer, product and service performance, operations, market, competitive comparisons, suppliers, employee-related, cost and financial. Analysis refers to the process of extracting larger meaning from data to support evaluation and decision making at various levels within the company. Such analysis may entail using data to reveal information - such as trends, projections, and cause and effect - that might not be evident without analysis. Facts, data, and analysis support a variety of company purposes, such as planning, reviewing company performance, improving operations, and comparing company quality performance with competitors' or with "best practices" benchmarks.

\section{Partnership Development}

Companies should seek to build internal and external partnerships to better accomplish their overall goals. Internal partnerships may include those that promote labormanagement cooperation, such as agreements with unions. Agreements may entail employee development, cross-training, or new work organizations, such as high performance work teams.

Examples of external partnerships include those with customers, suppliers, and education organizations. An increasingly important kind of external partnership is the strategic partnership or alliance. Such partnerships might offer a company entry into new markets or a basis for new products or services.

\section{Responsibility and Citizenship}

A company's quality system objectives should address corporate responsibility and citizenship. Corporate responsibility includes business ethics, and protection of public health, public safety, and the environment. Health, safety and environmental considerations need to take into account the company's operations as well as the life cycles of products and services. Companies need to address factors such as waste reduction at its source. Quality planning related to public health, safety and environment should anticipate adverse impacts that may arise in facilities management, production, distribution, transportation, use and disposal of products. Plans should seek avenues to avoid problems, to provide forthright company response if problems occur, and to make available information needed to maintain public awareness, safety, trust, and confidence.

Corporate citizenship refers to leadership and support of publicly important purposes. Such purposes might include education, resource conservation, community services, improving industry and business practices, and sharing of nonproprietary qualityrelated information. 


\section{AWARD CRITERIA FRAMEWORK}

The core values and concepts are embodied in seven categories as outlined in Figure 1. These criteria are combined into a framework for building a world class company as depicted in Figure 2.

\section{FIGURE 2 : Award Criteria Framework}

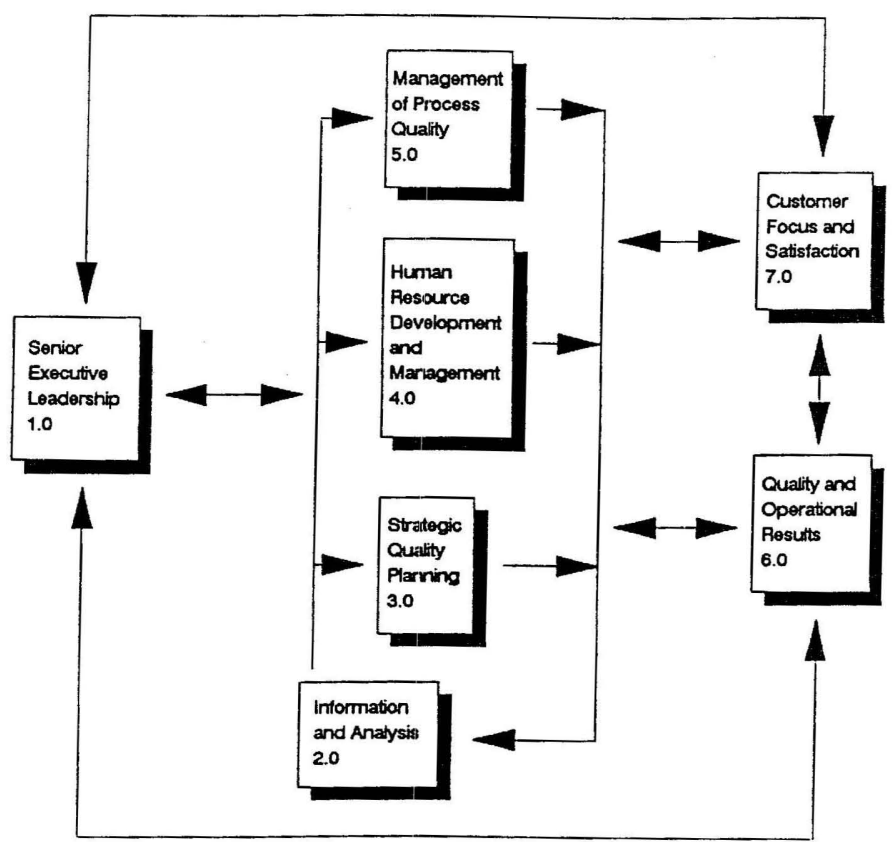

The framework has four basic elements:

Driver. Senior executive leadership creates the values, goals, and systems and then guides the sustained pursuit of quality and performance objectives.

System. The system comprises of the set of well-defined and well-designed processes for meeting the company's quality and performance requirements.

- Measures of progress. Measures of progress provide a results-oriented basis for channeling actions to delivering ever-improving custormer value and company performance.

- Goal. The basic aim of the quality process is the delivery of ever-improving values to customers. 
FIGURE 1 : 1992 Examination Categories/Items

Point Values

1.0 Leadership

1.1 Senior Executive Leadership

1.2 Management for Quality

1.3 Public Responsibility

2.0 Information and Analysis

2.1 Scope and Management of Quality and Performance Data and Information

2.2 Competitive Comparisons and Benchmarks

2.3 Analysis and Uses of Company-Level Data

3.0 Strategic Quality Planning

$\begin{array}{lll}3.1 & \text { Strategic Quality and Company Performance Planning Process } & 35 \\ 3.2 & 25\end{array}$

3.2 Quality and Performance Plans

4.0 Human Resource Development and Management

4.1 Human Resource Management 20

4.2 Employee Involvement 40

4.3 Employee Education and Training 40

4.4 Employee Performance and Recognition. 25

4.5 Employee Well-Being and Morale $\quad 25$

$\begin{array}{ll}\text { 5.0 Management of Process Quality } & 140\end{array}$

5.1 Design and Introduction of Quality Products and Services 40

5.2 Process Management - Product and Service Production and

Delivery Processes $\quad 35$

5.3 Process Management - Business Processes and Support Services 30

$\begin{array}{lll}5.4 & \text { Supplier Quality } & 20\end{array}$

5.5 Quality Assessment 15

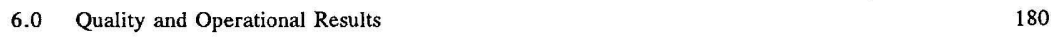

$\begin{array}{lll}\text { 6.1 Products and Service Quality Results } & 75\end{array}$

6.2 Company Operational Results 45

6.3 Business Process and Support Service Results 25

6.4 Supplier Quality Results $\quad 35$

$\begin{array}{llr}7.0 & \text { Customer Focus and Satisfaction } & 300\end{array}$

$\begin{array}{lll}7.1 & \text { Customer Relationship Management } & 65\end{array}$

7.2 Commitment to Customers 15

7.3 Customer Satisfaction Determination $\quad 35$

$\begin{array}{lll}7.4 & \text { Customer Satisfaction Results } & 75\end{array}$

$\begin{array}{lll}7.5 & \text { Customer Satisfaction Comparison } & 75\end{array}$

7.6 Future Requirements and Expectations of Customers 35

$\begin{array}{ll}\text { TOTAL POINTS } & 1000\end{array}$ 


\section{CATEGORY 1 : LEADERSHIP}

The recurring theme in current total quality management literature is the importance of senior management involvement. Without fail this aspect is defined as the one prerequisite for success for any company venturing to become world class. It is not good enough for company leaders to preach total quality - it must be obvious from their actions. An organization cannot be changed by proclamation - management must "walk the talk". Key executives can only convince the rest of the organization by their visible behaviour, by being role models, by being consistent and showing that their actions match their words. Management must realize that "they watch your feet not your lips".

The Leadership Category examines senior executives' personal leadership and involvement in creating and sustaining a customer focus and clear visible quality values. Also examined is how the quality values are integrated into the company's management system and reflected in the manner in which the company addresses its public responsibilities.

\section{Senior Executive Leadership}

Describe the senior executives' leadership, personal involvement, and visibility in developing and maintaining a customer focus and an environment for quality excellence.

\section{Management for Quality}

Describe how the company's customer focus and quality values are integrated into dayto-day leadership, management, and supervision of all company units.

\section{Public Responsiblity}

Describe how the company includes its responsiblities to the public for health, safety, environmental protection, and ethical business practices in its quality policies and improvement activities, and how it provides leadership in external groups.

\section{CATEGORY 2 : INFORMATION AND ANALYSIS}

This category evaluates the neural network of a company. If the information and analysis systems of a company are sufficient, the company will function in a coherent manner. If insufficient a company is unable to make rational decisions both at a strategic and at an operational level. The next category, Strategic Quality Planning, is dependant on the effectiveness of a companies information and analysis systems. 
The Information and Analysis Category examines the scope, validity, analysis, management, and use of data and information to drive quality excellence and improve competitive performance. Also examined is the adequacy of the company's data, information, and analysis system to support improvement of the company's customer focus, products, services, and internal operations.

\section{Scope and Management of Quality and Performance. Data and Information}

Describe the company's base of data and information used for planning, day-to-day management, and evaluation of quality. Describe also how data and information reliability, timeliness, and access are assured.

\section{Competitive Comparisons and Benchmarks}

Describe the company's approach to selecting data and information for competitive comparisons and world-class benchmarks to support quality and performance planning, evaluation, and improvement.

Analysis and Uses of Company-Level Data

Describe how quality- and performance-related data and information are analyzed and used to support the company's overall operational and planning objectives.

\section{CATEGORY 3 : STRATEGIC QUALITY PLANNING}

The only way a company can develop a sustainable competitive advantage over its competition is to pay attention to both what it do for the customer and how it is done. Total quality, as seen by customers, includes both the strategic aspects of the product or service offering (doing the right thing) and the excellence of execution of that product or service (doing it right the first time).

The Strategic Quality Planning Category examines the company's planning process and how all key quality requirements are integrated into overall business planning. Also examined are the company's short-and longer-term plans and how quality and performance requirements are deployed to all work units.

\section{Strategic Quality and Company Performance Planning Process}

Describe the company's strategic planning process for the short term (1-2 years) and longer term (3 years or more) for quality and customer satisfaction leadership. Include how this process integrates quality and company performance requirements and how plans are deployed.

\section{Quality and Performance Plans}

Summarize the company's quality and performance plans and goals for the short term ( $1-2$ years) and the longer term ( 3 years or more). 


\section{CATEGORY 4 : HUMAN RESOURCE DEVELOPMENT AND MANAGEMENT}

The key to harnassing the human potential of any company, in its strive to excellence, is contained in the two words "empowerment" and "ownership". John F Akers, chairman of IBM Corporation formulates it as follows:

"Empowering our employees and inculcating a sense that everyone own his or her piece of the business not only unleashes the talent and energy of our people, but also flattens the organization and reduces stifling bureaucracy".

The Human Resource Development and Management Category examines the key elements of how the company develops and realizes the full potential of the work force to persue the company's quality and performance objectives. Also examined are the company's efforts to build and maintain an environment for quality excellence conducive to full participation and personal and organizational growth.

\section{Human Resource Management}

Describe how the company's overall human resource development and management plans and practices support its quality and company performance plans and address all categories and types of employees.

\section{Employee Involvement}

Describe the means available for all employees to contribute effectively to meeting the company's quality and performance objectives; summarize trends in involvement.

\section{Employee Education and Training}

Describe how the company determines what quality and related education and training is needed by employees and how the company utilizes the knowledge and skills acquired; summarize the types of quality and related education and training received by employees in al categories.

\section{Employee Performance and Recognition}

Describe how the company's employee performance, recognition, promotion, compensation, reward, and feedback processes support the attainment of the company's quality and performance objectives.

\section{Employee Well-Being and Morale}

Describe how the company maintains a work environment conducive to the well-being and growth of all employees; summarize trends and levels in key indicators of wellbeing and morale. 


\section{CATEGORY 5 : MANAGEMENT OF PROCESS QUALITY}

Category 5 covers design, production, support services, supplier quality and quality assessment. These elements are all included in the requirements of the SABS 0157/ISO 9000 series of standards for quality management systems.

Good manufacturing practices will not yield products or services that delight the customer if the marketing analysis or design is flawed. This section covers the translation of the customer's voices into designs, validating the designs, developing control plans, and improving the design process (with respect to both the cycle time and quality of the product or service development).

In the design stage, control plans need to address what the process should be doing and what can go wrong. Process flow charts, failure mode and effects analysis, and characteristic matrixes can be used to develop the plans. Ideas on how to simplify the process and reduce response time should be implemented before the product or service is introduced.

Along with developing control plans, key characteristics should be selected in the design phase. Contemporary thinking maintains that all characteristics must be within specification, but, in some cases, it is worth the effort to reduce the variation even further to be on target. This is demonstrated in a study conducted by the Ford Motor Company which compares transmissions manufactured in the United States and in Japan. Although both transmission manufacturers used the same blueprints and the transmissions were used in the same car line, the Japanese transmissions were experiencing only one-third of the warranty cost. The difference was due to the difference in production philosophies : A tolerance philosophy (all parts within specification are equally good) to a target philosophy (parts should meet a specified target).

The production and delivery process should be controlled and improved through rootcause analysis for solving process problems, the use of process control plans for monitoring and improving processes, and through measurement of the results achieved. There is no right way to carry out these activities. Whether a company uses the Shewhart cycle (plan, do, study, act) or any other approach to solve problems is not the issue. Instead, the issue is whether the company uses a systematic problem-solving process and whether that process incorporates problem prevention. In manufacting, the process control plan should answer the question, "What is the process doing?", with tools such as statistical process control and process capability studies.

Support organizations include finance, accounting, software services, sales, marketing, information services, purchasing, personnel, legal services, plant and facilities management, research and development, and secretarial and other administrative services. At companies where the quality initiative is mature, these areas are delighting their customers, simplifying their processes, and improving the accuracy of their output.

At world class companies, suppliers are now part of the team rather than being treated as adversaries, as they had been in the past. Their ideas and input are valued in the concept and design stage, not just at the manufacturing stage. Such partnerships provide a win-win relationship. 
The Management of Process Quality Category examines the systematic processes the company uses to pursue ever higher quality and company performance. Examined are the key elements of process management, including design, management of process quality for all work units and suppliers, systematic quality improvement, and quality assessment.

\section{Design and Introduction of Quality Products and Services}

Describe how new and/or improved products and services are designed and introduced and how processes are designed to meet key products and service quality requirements and company performance requirements.

Process Management - Products and Service Production and Delivery Processes

Describe how the company's products and service production and delivery processes are managed so that current quality requirements are met and quality and performance are continuously improved.

\section{Process Management - Business Processes and Support Services}

Describe how the company's business processes and support services are managed so that current requirements are met and quality and performance are continuously improved.

\section{Supplier Quality}

Describe how the quality of materials, components, and services furnished by other businesses is assured and continuously improved.

\section{Quality Assessment}

Describe how the company assesses the quality and performance of its systems, processes, and practices and the quality of its products and services.

\section{CATEGORY 6 : QUALITY AND OPERATIONAL RESULTS}

Results are the window to reality. Timely tracking of the right measures and effective presentation of the results enables an organization to do the right things right the first time.

This category represents the company's control room. It is the feedback loop of the quality system which provides key measures for evaluating and improving quality system processes and practices. The following questions can provide a quick check on the value of a proposed measure:

Does it relate, directly or indirectly to the ultimate goal of customer satisfaction?

Is the measure operationally defined? 
Is it understood in the same way by all concerned?

Is the measure important?

Do all parties agree that this measure needs to be watched closely and acted on if its performance is less than desirable?

Is it something that should be continuously improved?

Does it affect another important measure?

Does the benefit exceed the cost of taking the measurement?

The Quality and Operational Results Category examines the company's quality levels and improvement trends in quality, company operational performance, and supplier quality. Also examined are current quality and performance levels relative to those of competitors.

\section{Products and Service Quality Results}

Summarize trends in quality and current quality levels for key products and service features; compare the company's current quality levels with those of competitors.

\section{Company Operational Results}

Summarize trends and levels in overall company operational performance and provide a comparison of this performance with competitors and appropriate benchmarks.

\section{Business Process and Support Service Results}

Summarize trends and current levels in quality and performance improvement for business processes and support services.

\section{Supplier Quality Results}

Summarize trends in quality and current quality levels of suppliers; compare the company's supplier quality with that of competitors and with key benchmarks.

\section{CATEGORY 7 : CUSTOMER FOCUS AND SATISFACTION}

James Teboul proposes that a company should move from a position of quality by default to one of quality by excess. Quality is thereby transformed from a passive property into a strategic weapon which can be wielded in the market place to devastating effect.

It is therefore not good enough to give the "normal" satisfaction the client is entitled to expect, but to build the competitive advantage which will make the difference and delight the customer. 
The Customer Focus and Satisfaction Category examines the company's relationships with customers and its knowledge of customer requirements and of the key quality factors that determine marketplace competitiveness. Also examined are the company's methods to determine customer satisfaction, current trends and levels of satisfaction, and these results relative to competitors.

\section{Customer Relationship Management}

Describe how the company provides effective management of its relationship with its customers and uses information gained from customers to improve customer relationship management strategies and practices.

\section{Commitment to Customers}

Describe the company's explicit and implicit commitments to customers regarding its products and services.

\section{Customer Satisfaction Determination}

Describe the company's methods for determining customer satisfaction and customer satisfaction relative to competitors; describe how these methods are evaluted and improved.

\section{Customer Satisfaction Results}

Summarize trends in the company's customer satisfaction and trends in key indicators of dissatisfaction.

\section{Customer Satisfaction Comparison}

Compare the company's customer satisfaction results with those of competitors.

\section{Future Requirements and Expectations of Customers}

Describe how the company determines future requirements and expectations of customers.

\section{CONCLUSION}

The key to the economic survival of a company (or a country) lies in the quality of the products and services that it offers. Commitment to the total quality philosophy (doing the right things right the first time), will necessarily lead to an improvement in productivity and profitability.

South Africa, when compared to virtually any other developing or developed country, is on the bottom rung of the quality and productivity ladder. We can no longer afford to wait for "somebody" to take the lead as far as these issues are concerned. Each one of us should take the responsibility to promote and instill the total quality philosophy at home and at work. The Malcolm Baldridge Award Criteria highlights the values and principles to be considered 
when enbarking on the quality journey. These criteria can serve as a useful reference point when a company structures its quality improvement efforts.

\section{REFERENCES}

1. Sullivan R.L., Inside the Baldrige Award Guidelines - Category 1 : Leadership, Quality Progress, June 1992.

2. Omdahl T., Inside the Baldridge Award Guidelines - Category 2 : Information and Analysis, Quality Progress, July 1992.

3. Marquardt I.A., Inside the Baldridge Award Guidelines - Category 3 : Strategic Quality Planning, Quality Progress, August 1992.

4. Leifeld N, Inside the Baldridge Award Guidelines - Category 4 : Human Resource Development and Management, Quality Progress, September 1992.

5. Sunday J.L. and Liberty L., Benchmarking the Baldridge Award, Quality Progress, September 1992.

6. Heaphy M.S., Inside the Baldridge Award Guidelines - Category 5 : Management of Process Quality, Quality Progress, October 1992.

7. Case K.E. and Bigelow J., Inside the Baldridge Award Guidelines - Category 6 : Quality and Operational Results, Quality Progress, November 1992.

8. Desatnick R.L., Inside the Baldridge Award Guidelines - Category 7 : Customer Focus and Satisfaction, Quality Progress, December 1992.

9. Teboul J., Managing Quality Dynamics, Prentice Hall, 1991.

10. 1992 Award Criteria booklet, National Institute of Standards and Technology, Gaithersburg, MD. 